\title{
Comparison of Platinum, Rhodium, and Palladium Bioaccumulation by Sinapis alba and their Influence on Phytochelatin Synthesis in Plant Tissues
}

\author{
Katarzyna Kińska, Joanna Kowalska* \\ Faculty of Chemistry, University of Warsaw, Pasteura 1, 02-093, Warsaw, Poland
}

Received: 12 January 2018

Accepted: 25 March 2018

\begin{abstract}
Phytochelatins are known to play an essential role in xenobiotic detoxification in some plants. Until now, their synthesis in plants exposed to platinum group elements (PGEs), especially Pd and $\mathrm{Rh}$, has not been directly proven. The influence of PGEs on the natural environment, especially on living organisms, is particularly important in view of increasing emissions of these elements from automotive catalytic converters. This paper describes studies related to the identification of the presence of phytochelatins in tissues of white mustard (Sinapis alba L.) exposed to Pt, Rh, and Pd salts. Phytochelatins were identified by high-performance liquid chromatography with two types of detection: fluorescence (FLD) for thiols after derivatization, and electrospray ionization mass spectrometry (ESI MS) for thiols in fresh extracts. Our study confirmed the synthesis of phytochelatins in some plant organs under the influence of PGEs, and illustrated the differences in plant response to stress caused by $\mathrm{Pt}, \mathrm{Rh}$, or Pd.
\end{abstract}

Keywords: platinum, palladium, rhodium, phytochelatins, heavy metal stress

\section{Introduction}

The widespread introduction of automobile catalytic converters has increased emissions of platinum group elements (PGEs) into the environment. Thus, PGEs are a matter of concern for environmental chemists interested in contamination of roadside ecosystems [1-5]. The level of PGEs in some places, especially Pd and $\mathrm{Pt}$, exceeds $500 \mathrm{ng} \mathrm{g}^{-1}$ [6-8]. Although PGEs are

*e-mail: askow@chem.uw.edu.pl emitted in inert form, once they encounter various soil compounds these elements can be incorporated into bioavailable molecules, as has been observed, especially in the case of Pd [9]. As with other metal ions, PGEs could be taken up by plants, causing dysfunction [10, 11]. Analyses of various plants collected near roadways have shown that Pd exhibits the highest bioavailability, followed by $\mathrm{Rh}$ and $\mathrm{Pt}$ [3]. The literature suggests that metal ions absorbed from soil through the roots can be bound by sulfur-rich substances [12, 13]. The accumulation process takes place mainly in the vegetative parts of plants and decreases in the following 
order: root $>$ stem $>$ leaves $[10-12,14,15]$. Like $\mathrm{Cu}$ and $\mathrm{Ni}$, PGEs are considered to be poorly to moderately bioavailable metals [16]. As a response to physiologically unsuitable ecosystem conditions, plants have developed a number of mechanisms to protect them from stress [17]. Synthesis of phytochelatins (PCs) is an important process controlling the concentration of some metal ions inside the plant cells [18]. These low molecular weight peptides (with the structure of ( $\gamma$-Glu-Cys) $\mathrm{n}$-Gly, $\mathrm{n}=2-11$ ) are able to form complexes with metal ions, and then transport the complexes to the vacuole [19]. The synthesis of PCs in higher plants has been demonstrated under the influence of $\mathrm{Cd}, \mathrm{Pb}$, or $\mathrm{As}$ [20-22]. Recently the influence of Pt(IV) on the activity of the phytochelatin synthase enzyme, which is involved in the formation of phytochelatins, was examined in maize and pea [23]. The synthesis of phytochelatins has also been confirmed in the tissues of Arabidopsis thaliana $\mathrm{L}$ and Sinapis alba L. under the influence of $\operatorname{Pt}(\mathrm{II})[10,24]$. So far there is no available information about PCs synthesis in plants under exposure to stress associated with the presence of other PGEs. Nevertheless, some authors have suggested that this mechanism could be worth consideration [25].

The main goal of the study was to prove that PCs are involved in the detoxification process of $\mathrm{Pt}, \mathrm{Pd}$, and $\mathrm{Rh}$ taken up by $S$. alba, described in the literature as a species with a high xenobiotics bioaccumulation factor $[21,26]$.

\section{Material and Methods}

\section{Cultivation of Sinapis alba $\mathrm{L}$.}

Sinapis alba L. was cultivated in nutrient solution containing the following: $500 \mathrm{mg} \mathrm{L}-1 \mathrm{Ca}\left(\mathrm{NO}_{3}\right)_{2} \cdot 4 \mathrm{H}_{2} \mathrm{O}$, $150 \mathrm{mg} \mathrm{L} \mathrm{KNO}_{3}, 150 \mathrm{mg} \mathrm{L}^{-1} \mathrm{MgSO}_{4}, 150 \mathrm{mg} \mathrm{L}^{-1}$ $\mathrm{KH}_{2} \mathrm{PO}_{4}, 0.482 \mathrm{mg} \mathrm{L} \mathrm{L}^{-1} \mathrm{MnSO}_{4} \cdot 5 \mathrm{H}_{2} \mathrm{O}, 0.0185 \mathrm{mg} \mathrm{L}^{-1}$ $\left(\mathrm{NH}_{4}\right)_{6} \mathrm{Mo}_{7} \mathrm{O}_{24} \cdot 4 \mathrm{H}_{2} \mathrm{O}, 8.0 \mathrm{mg} \mathrm{L}^{-1}$ EDTAFeNa, $1.25 \mathrm{mg} \mathrm{L}^{-1}$ $\mathrm{CuSO}_{4} \cdot 5 \mathrm{H}_{2} \mathrm{O}, 0.575 \mathrm{mg} \mathrm{L}^{-1} \mathrm{ZnSO}_{4} \cdot 7 \mathrm{H}_{2} \mathrm{O}$, and $1 \mathrm{~mL}$ of $1 \mathrm{~mol} \mathrm{~L}^{-1}$ Tris (hydroxymethyl) aminomethane (all reagents were of analytical grade). $4 \mathrm{~L}$ containers ( 9 seedlings per container) were placed in a growth chamber at $22^{\circ} \mathrm{C} / 20^{\circ} \mathrm{C} \quad(16 \mathrm{~h}$ day $/ 8 \mathrm{~h}$ night) and continuously aerated. White mustard grew for a period of 3 weeks. After one week, nutrient solutions were supplemented with $0.5 \mathrm{mg} \mathrm{L}^{-1}$ or $1.0 \mathrm{mg} \mathrm{L}^{-1} \mathrm{Pt}$, $\mathrm{Pd}$ or $\mathrm{Rh}$ chloride, introduced as a $1 \mathrm{~g} \mathrm{~L}^{-1}$ stock solution, and plants $(n=9)$ were exposed to the presence of xenobiotic for 2 weeks. After 3 weeks plants were harvested and split into leaves, stems, and roots, or roots and aboveground parts. Oven-dried plant material $\left(60^{\circ} \mathrm{C}\right)$ was pulverized in an agate ball mill (FRITSCH, Germany).

\section{Total Elements Content Analysis}

Homogenised samples of dried leaves, stems, and roots were digested with concentrated nitric acid in an
Ethos 1 Advanced Microwave System (Milestone, Italy) according to the procedure described in the previous paper [26]. In short, 100-250 $\mathrm{mg}$ homogenized plant materials were placed in a Teflon vessel and digested for 45 min with $3.0 \mathrm{~mL}$ concentrated nitric acid in a close microwave system $\left(5 \min 20-90^{\circ} \mathrm{C} ; 10 \min 90-170^{\circ} \mathrm{C}\right.$, 30 min $170-200^{\circ} \mathrm{C}$ ). Each sample was digested at least 3 times. After digestion, samples were diluted with ultrapure water obtained with Milli-Q System (Millipore, USA) to a volume of $25 \mathrm{~mL}$. The measurements of total content of platinum, palladium, and rhodium in plant tissues were carried out with an ICP MS (Nexion 300D, Perkin Elmer, USA) after appropriate sample dilution. During ICP MS three isotopes of Pt $\left({ }^{194} \mathrm{Pt},{ }^{195} \mathrm{Pt},{ }^{196} \mathrm{Pt}\right)$, three isotopes of $\mathrm{Pd}\left({ }^{105} \mathrm{Pd},{ }^{106} \mathrm{Pd},{ }^{108} \mathrm{Pd}\right)$, and one isotope for ${ }^{103} \mathrm{Rh}$ were controlled. The relative abundance of isotopes was in good agreement with those obtained for standard solutions of Pt and Pd.

\section{Derivatized Thiol Compounds Analysis}

In order to verify the presence of phytochelatins in Sinapis alba L. tissues, during presented studies two analytical techniques of increasing sophistication were used. As phytochelatins are known to be very unstable, to indicate their presence in plant tissue a derivatization procedure was simultaneously performed. Detailed procedure of thiol analysis was described in our previous work [26]. Shortly, $300 \mathrm{mg}$ of fresh plant material with the addition of $1 \mathrm{~mol} \mathrm{~L}^{-1}$ $\mathrm{NaOH}(100 \mu \mathrm{L}), 6 \mathrm{~mol} \mathrm{~L}^{-1} \mathrm{NaBH}_{4}(100 \mu \mathrm{L}), 6.3 \mathrm{mmol} \mathrm{L}^{-1}$ DTPA $(1.8 \mathrm{~mL})$, and quartz sand were ground in a mortar. $250 \mu \mathrm{L}$ of centrifuged solution was mixed with $200 \mathrm{mmol} \mathrm{L}-1$ HEPPS buffer $(450 \mu \mathrm{L})$ and $20 \mathrm{mmol} \mathrm{L}^{-1}$ monobromobimane $(\mathrm{mBBr})(10 \mu \mathrm{L})$. After $30 \mathrm{~min}$ of thiol derivatization, $1 \mathrm{~mol} \mathrm{~L}^{-1}$ methanesulphonic acid (MSA) $(300 \mu \mathrm{L})$ was added to stop the reaction. Analysis by HPLC FLD (Agilent Technologies, USA) was carried out under the conditions optimized and described in previous studies [21]. Filtrated $(0.45 \mu \mathrm{m}$ syringe filter) sample of derivatized thiols was separated on $\mathrm{C} 18$ column (Zorbax XDB, $4.6 \times 250 \mathrm{~mm}$, Agilent Technologies, USA) with $0.1 \%$ trifluoroacetic acid (TFA) and acetonitrile (ACN) in gradient elution program (0-10 min with $8-12 \% \mathrm{ACN}$ and 10-40 min with $12-35 \% \mathrm{ACN})$. Qualitative and quantitative analysis of phytochelatins in plant tissues was made by HPLC FLD method by comparing heights and retention times of signals received for filtrates, to peaks obtained for standard solutions: $\mathrm{PC}_{2}(22.5 \mathrm{~min})$, $\mathrm{PC}_{3}(26.5 \mathrm{~min})$, and $\mathrm{PC}_{4}(29.1 \mathrm{~min}$.).

\section{Underivatized Thiol Compounds Analysis}

Extraction of thiols was conducted with $1 \%$ formic acid $(\mathrm{HCOOH})$ on triturated in the presence of liquid nitrogen fresh plant material according to a procedure described previously [24]. The samples were shaken for 90 minutes at $1^{\circ} \mathrm{C}$ (JWE 357, Poland) and then centrifuged at $6000 \mathrm{rpm}$ at $1^{\circ} \mathrm{C}$ for $5 \mathrm{~min}(5430 \mathrm{R}$, 


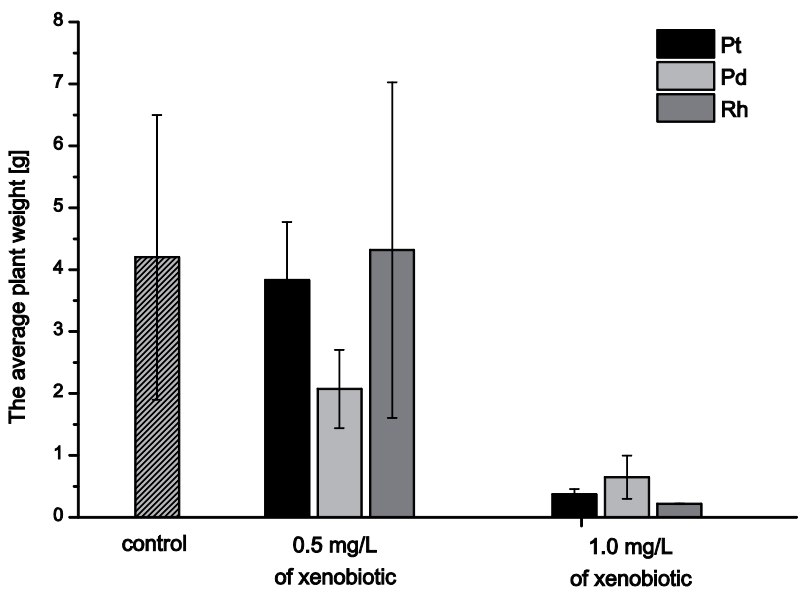

Fig. 1. Average biomass of whole Sinapis alba plant $(\mathrm{n}=9)$, hydroponicaly cultivated with the addition of $0.5 \mathrm{mg} \mathrm{L}^{-1}$ or $1.0 \mathrm{mg} \mathrm{L}^{-1}$ of platinum, palladium, or rhodium salts.

Eppendorf, Germany) and filtered $(0.45 \mu \mathrm{m})$. ESI MS analysis of all plant extracts containing underivatized thiol compounds was completed within 8 hours in a 3200 QTRAP System (SCIEX, USA) connected with a Shimadzu LC System (Shimadzu, Japan). LC-MS/ MS analysis started with chromatographic separation on C18 column (Luna, $100 \times 2.1 \mathrm{~mm}, 5 \mu \mathrm{m}$, Phenomenex, USA) with a mobile phase consisting of $8 \mathrm{mmol} \mathrm{L}^{-1}$ $\mathrm{HCOOH}$ and $\mathrm{ACN}$ in gradient mode (0-5 $\mathrm{min} 8 \%$ $\mathrm{ACN}, 5-15 \min 8-35 \% \mathrm{ACN}, 15-16 \min 35 \% \mathrm{ACN}$, $16-18$ min $35-80 \%$ ACN, 18-21 min $80 \%$, 21-22 min $80-8 \%$ ). Phytochelatins, obtained in positive-ion mode, were identified based on $\mathrm{m} / \mathrm{z}$ value by $\mathrm{MS}$ and retention times of signals obtained for samples and standard solutions. $\mathrm{PC}_{2}(\mathrm{mBBr})_{2} \mathrm{M}^{+} \mathrm{m} / \mathrm{z} 920(15.0 \mathrm{~min})$, $\mathrm{PC}_{3}(\mathrm{mBBr})_{3} \mathrm{M}^{+} \mathrm{m} / \mathrm{z} \mathrm{1342}$, and $\mathrm{M}^{2+} \mathrm{m} / \mathrm{z} 672$ (17.0 min); $\mathrm{PC}_{4}(\mathrm{mBBr})_{4} \mathrm{M}^{2+} \mathrm{m} / \mathrm{z} 883$ (19.0 min) were checked for thiols after derivatization, while in samples without thiols derivatization the following signals were monitored: $\mathrm{PC}_{2} \mathrm{~m} / \mathrm{z} 540$ (3.4 min), $\mathrm{PC}_{3} \mathrm{~m} / \mathrm{z} 772$ (6.4 min), and $\mathrm{PC}_{4}$ $\mathrm{m} / \mathrm{z} 1004$ (11.8 $\mathrm{min})$ [27].

All graphs were prepared in Origin 8.5 software (OriginLab, USA).

Table 1. Total contents of Pt, $\mathrm{Pd}$, and $\mathrm{Rh}$ in Sinapis alba tissues $\left(\mathrm{C}+\mathrm{SD} / \mu \mathrm{g} \mathrm{g}^{-1}\right.$ d.w.; $\left.\mathrm{n}=3\right)$.

\begin{tabular}{|c|c|c|c|}
\hline & $\mathrm{Pt}$ & $\mathrm{Pd}$ & $\mathrm{Rh}$ \\
\hline \multicolumn{4}{|c|}{$0.5 \mathrm{mg} \mathrm{L}{ }^{-1}$} \\
\hline Leaves & $1.06 \pm 0.02$ & $1.05 \pm 0.06$ & $2.55 \pm 0.03$ \\
\hline Steams & $14.9 \pm 0.4$ & $51.6 \pm 5.0$ & $7.8 \pm 0.1$ \\
\hline Roots & $762 \pm 20$ & $663 \pm 12$ & $437 \pm 59$ \\
\hline \multicolumn{4}{|c|}{$1 \mathrm{mg} \mathrm{L}^{-1}$} \\
\hline Aboveground parts & $95.8 \pm 1.2$ & $30.6 \pm 1.4$ & $145 \pm 6$ \\
\hline Roots & $5973 \pm 140$ & $1958 \pm 40$ & $74.2 \pm 1.2$ \\
\hline
\end{tabular}

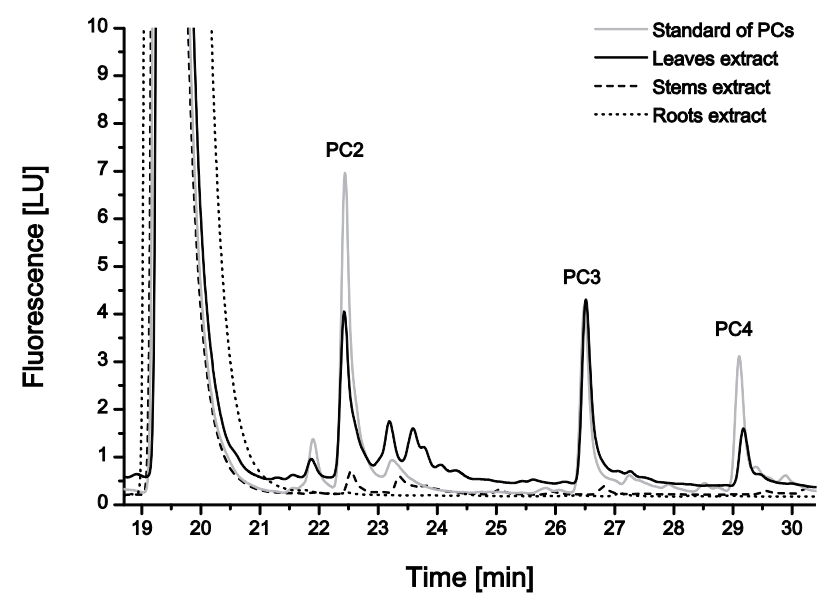

Fig. 2. The HPLC FLD chromatograms of derivatized extract from roots, stems, and leaves of Sinapis alba L. exposed to $1.0 \mathrm{mg} \mathrm{L}^{-1} \mathrm{PdCl}_{2}$ for 2 weeks, and a derivatized mixture of three phytochelatins $\left(\mathrm{PC}_{2}, \mathrm{PC}_{3}\right.$, and $\left.\mathrm{PC}_{4}\right)$

\section{Results and Discussion}

Analysis of plants cultivated with $1 \mathrm{mg} \mathrm{L}^{-1}$ of PGEs revealed significant biomass reduction in comparison to control plants cultivated without xenobiotics (Fig. 1). The plants exposed to the higher concentration of PGEs suffered stunted growth, deformation, discoloration, and drying of leaves. For crops grown with the lower PGE concentration, considerable biomass reduction was observed only in the case of Pd.

Based on total element concentrations it was found that PGEs were absorbed by the plants' roots and transported to aboveground plant organs (Table 1). Simultaneous analysis of control plants showed $\mathrm{Pt}$, $\mathrm{Rh}$, and $\mathrm{Pd}$ concentrations not exceeding $0.1 \mu \mathrm{g} \mathrm{g}^{-1}$ in aboveground organs and $2.0 \mu \mathrm{g} \mathrm{g}^{-1}$ in roots. In PGE-treated cultivation, the highest accumulation factors $\left(\mathrm{AF}=\mathrm{C}_{\text {plant }} / \mathrm{C}_{\text {nutr.sol. }}\right.$ ) were reached for roots (up to 1500 for $0.5 \mathrm{mg} \mathrm{L}^{-1}$ and 6000 for $1 \mathrm{mg} \mathrm{L}^{-1}$ ). Only in the Rh-treated plants (cultivation with $1.0 \mathrm{mg} \mathrm{L}^{-1}$ ) AF for roots was below 100, two times lower than for aboveground parts, yielding a high translocation factor $\left(\mathrm{TF}=\mathrm{C}_{\text {shoot }} / \mathrm{C}_{\text {root }} \approx 2\right)$. This phenomenon had already been observed during our studies with thallium [21, 2830]. For Pt and Pd TF was about 0.015. Among plants cultivated with $0.5 \mathrm{mg} \mathrm{L}^{-1} \mathrm{PGE}$, TF were the highest for those treated with Pd, but did not exceed 0.08 for stems. Similar results were obtained when $\left[\mathrm{Pt}\left(\mathrm{NH}_{3}\right)_{4}\left(\mathrm{NO}_{3}\right)_{2}\right]$ was added to the nutrient solution $(\mathrm{TF} \approx 0.1)$ [24].

During these studies our attention was focused on identifying the presence of cysteine-containing phytochelatins in S. alba as stress metabolites. This kind of defense mechanism has been already proven in $S$. alba exposed to As [26] and $\mathrm{Pt}$ compounds $\left[\mathrm{Pt}\left(\mathrm{NH}_{3}\right)_{4}\left(\mathrm{NO}_{3}\right)_{2}\right]$ [24].

As far as synthesis of phytochelatins is considered, among all PGEs only responses of plants cultivated with $\mathrm{Pt}$ addition are described in the literature [24]. Based 


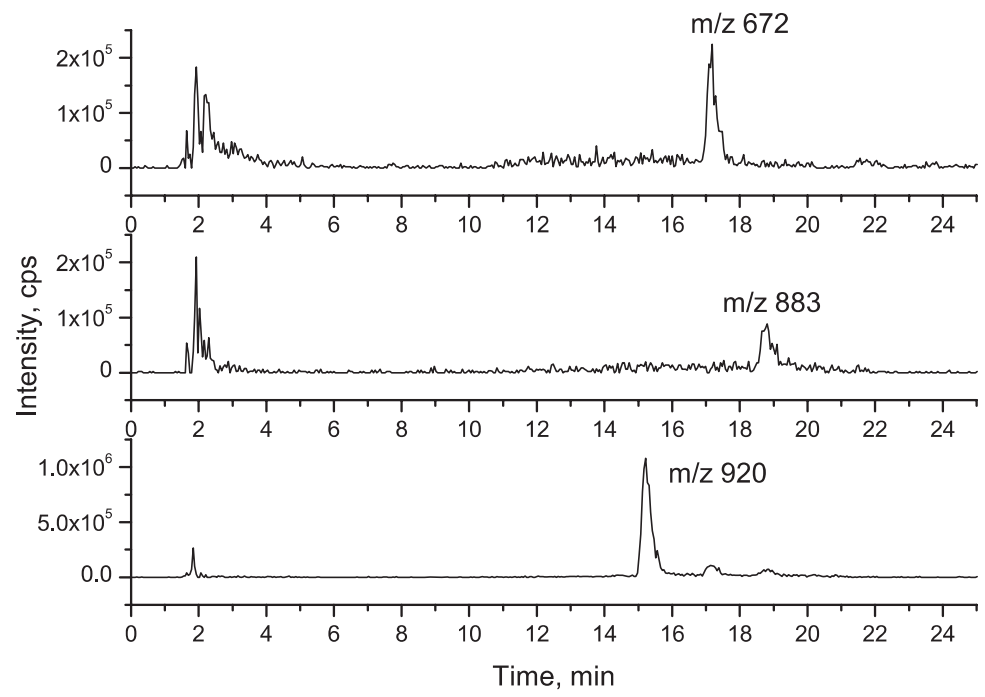

Fig. 3. HPLC ESI MS chromatograms of derivatized leaf extract of Sinapis alba L. exposed to $1.0 \mathrm{mg} \mathrm{L}^{-1} \mathrm{PdCl}_{2}$ for 2 weeks; peaks with pseudomolecular masses $\mathrm{m} / \mathrm{z}$ 672, 883, and 920 indicate the occurrence of $\mathrm{PC}_{3}\left(\mathrm{mBBr}_{3}, \mathrm{PC}_{4}\left(\mathrm{mBBr}_{4}\right.\right.$, and $\mathrm{PC}_{2}\left(\mathrm{mBBr}_{2}\right.$, respectively.

on the analysis completed by HPLC FLD (Fig. 2) and HPLC ESI MS (Figs 3-4), we found that phytochelatins are synthesized to the greatest extent in plants cultivated in the presence of palladium ions (Fig. 5). Regardless of the Pd concentration in nutrient solution, all three phytochelatins were detected in leaves of $S$. alba. In stems of plants treated with $1.0 \mathrm{mg} \mathrm{L}^{-1}$ of $\mathrm{Pd}$, two phytochelatins $\left(\mathrm{PC}_{2}\right.$ and $\left.\mathrm{PC}_{3}\right)$ were detected, while $0.5 \mathrm{mg} \mathrm{L}{ }^{-1}$ caused synthesis of phytochelatin $\mathrm{PC}_{2}$ only. No phytochelatin was observed in plant roots although the Pd concentration in roots was the highest. In leaves, stems, and roots of plants cultivated in the presence of $\mathrm{Pt}$, independent of xenobiotic concentration in nutrient solution, phytochelatin $\mathrm{PC}_{2}$ was detected, identically to $\left[\mathrm{Pt}\left(\mathrm{NH}_{3}\right)_{4}\left(\mathrm{NO}_{3}\right)_{2}\right]$-treated plants, as presented previously [24]. The higher Pt concentration $\left(1.0 \mathrm{mg} \mathrm{L}^{-1}\right)$ caused additional synthesis of phytochelatin $\mathrm{PC}_{3}$, but only in plant roots.

In the case of $\mathrm{Rh}$, as for $\mathrm{Pd}$, no phytochelatins were observed in plant roots, independent of $\mathrm{Rh}$ concentration in nutrient solution. Phytochelatin $\mathrm{PC}_{2}$ was detected in leaves of $S$. alba from both cultivations. The higher
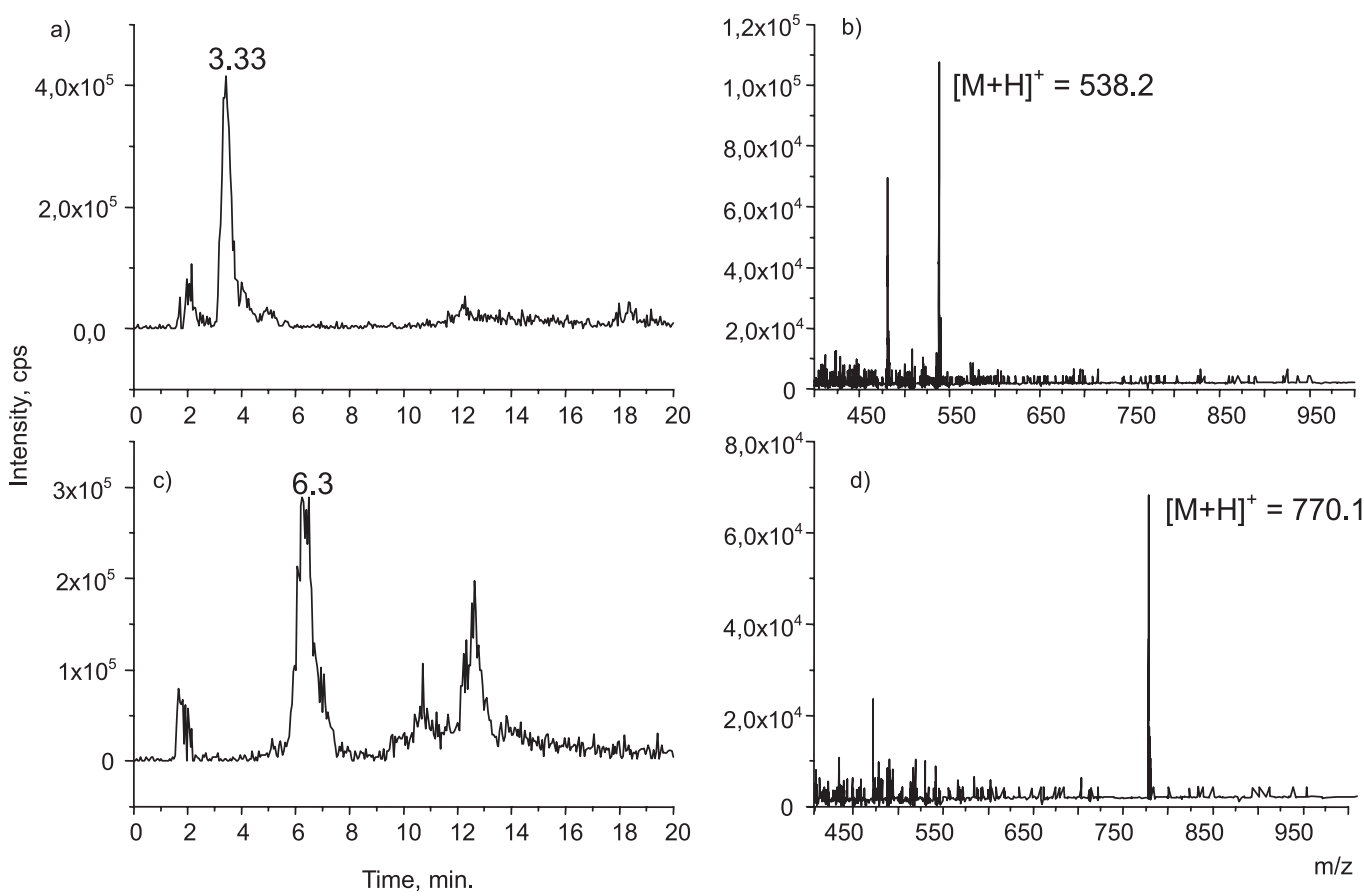

Fig. 4. HPLC ESI MS chromatograms recorded for leaf extract of Sinapis alba L. exposed to $1.0 \mathrm{mg} \mathrm{L}^{-1} \mathrm{PdCl}_{2}$ for 2 weeks; the peak on retention time $3.33 \mathrm{~min}(\mathrm{~A})$ with pseudomolecular mass $\mathrm{m} / \mathrm{z} 538.2$ (B) indicates the occurrence of free phytochelatin $\mathrm{PC}_{2}$, while the peak with retention time $6.3 \mathrm{~min}(\mathrm{C})$ with pseudomolecular mass $\mathrm{m} / \mathrm{z} 770.1$ (D) indicates the presence of free $\mathrm{PC}_{3}$. 


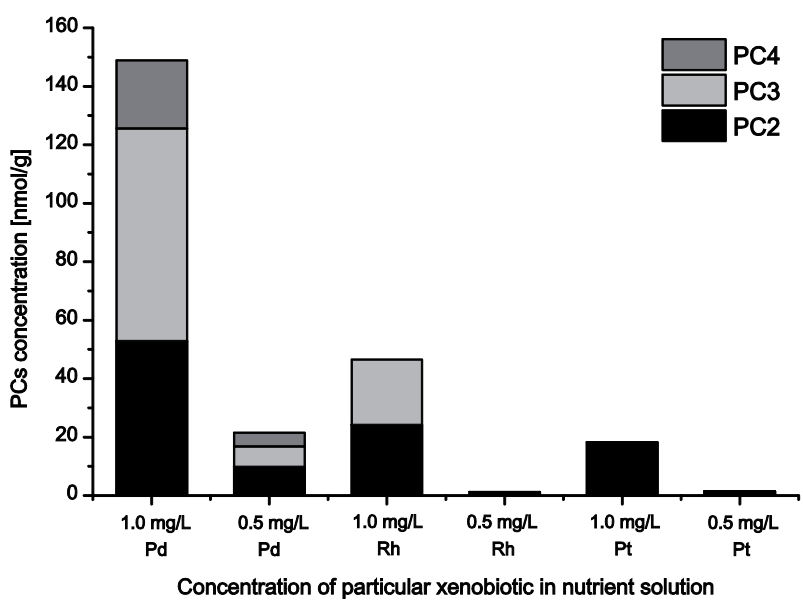

Fig. 5. Concentration of phytochelatins $\mathrm{PC}_{2}, \mathrm{PC}_{3}$, and $\mathrm{PC}_{4}$ in leaf extracts of Sinapis alba cultivated in nutrient solution with the addition of 1.0 or $0.5 \mathrm{mg} \mathrm{L}^{-1} \mathrm{Pd}, \mathrm{Rh}$, and Pt salts, respectively.

concentration of $\mathrm{Rh}$ caused synthesis of $\mathrm{PC}_{2}$ and $\mathrm{PC}_{3}$ in leaf and stem tissues.

\section{Conclusions}

Comparing the plant response to all three PGE salts, it should be underscored that they affect $S$. alba to different extents - not only where plant morphology is concerned. The strongest influence of xenobiotics on plant morphology, biomass production, and phytochelatin synthesis was observed in the case of Pd. The presence of phytochelatins in $S$. alba tissues suggests that PGEs are responsible for activation of the phytochelatin synthase enzyme and may be complexed by those metal-binding oligopeptides, which can reduce their potential toxicity.

\section{Acknowledgements}

Our study was supported by the National Science Centre (NCN), Poland (grant No. 2014/15/N/NZ8/00326). We kindly thank the Structural Research Laboratory at the Faculty of Chemistry, University of Warsaw for using HPLC ESI MS, and the University of Warsaw Biological and Chemical Research Centre for using ICP MS.

\section{Conflict of Interest}

The authors declare no conflict of interest.

\section{References}

1. RUCHTER N., SURES B. Distribution of platinum and other traffic related metals in sediments and clams (Corbicula sp.). Water Res 70, 313, 2015.
2. WANG Y., LI X. Health Risk of Platinum Group Elements from Automobile Catalysts. Procedia Eng 45, 1004, 2012

3. SOBROVA P., ZEHNALEK J., ADAM V., BEKLOVA M., KIZEK R. The effects on soil/water/plant/animal systems by platinum group elements. Cent Eur J Chem 10, 1369, 2012.

4. LEOPOLD K., WÖRLE K., SCHINDL R., HUBER L., MAIER M., SCHUSTER M. Determination of trafficrelated palladium in tunnel dust and roadside soil. Sci Total Environ 583, 169, 2017.

5. WISEMAN C.L.S., HASSAN POUR Z., ZEREINI F. Platinum group element and cerium concentrations in roadside environments in Toronto, Canada. Chemosphere 145, 61, 2016.

6. LYUBOMIROVA V., DJINGOVA R. Accumulation and Distribution of $\mathrm{Pt}$ and $\mathrm{Pd}$ in Roadside Dust, Soil and Vegetation in Bulgaria. In, Platinum Metals in the Environment, 243, Springer, Berlin, Heidelberg, 2015.

7. SPADA N., BOZLAKER A., CHELlAM S. Multielemental characterization of tunnel and road dusts in Houston, Texas using dynamic reaction cell-quadrupoleinductively coupled plasma-mass spectrometry: Evidence for the release of platinum group and anthropogenic metals from motor vehicles. Anal Chim Acta 735, 1, 2012.

8. ZHITENKO L.P., KISELEVA I.N., KHOMUTOVA E.G. Methods for studying anthropogenic environmental pollution with platinum group metals (Review). Inorg Mater 52, 1370, 2016.

9. ZEREINI F., WISEMAN C.L.S., VANG M., ALBERS P., SCHNEIDER W., SCHINDL R., LEOPOLD K. Geochemical behaviour of palladium in soils and $\mathrm{Pd} /$ PdO model substances in the presence of the organic complexing agents L-methionine and citric acid. Environ Sci Process Impacts 18, 22, 2016.

10. GAWROŃSKA H., PRZYBYSZ A., SZALACHA E., PAWLAK K., BRAMA K., MISZCZAK A., STANKIEWICZ-KOSYL M., GAWROŃSKI S.W. Platinum uptake, distribution and toxicity in Arabidopsis thaliana L. plants. Ecotoxicol Environ Saf 147, 982, 2018.

11. RONCHINI M., CHERCHI L., CANTAMESSA S., LANFRANCHI M., VIANELLI A., GEROLA P., BERTA G., FUMAGALLI A. Palladium uptake by Pisum sativum: partitioning and effects on growth and reproduction. Environ Sci Pollut Res 22, 7600, 2015.

12. PAWLAK J., ŁODYGA-CHRUŚCIŃSKA E., CHRUSTOWICZ J. Fate of platinum metals in the environment. J Trace Elem Med Biol 28, 247, 2014.

13. NOVO L.A.B., ONISHI V.C., BERNARDINO C.A.R., DA SILVA E.F. Metal Bioaccumulation by Plants in Roadside Soils: Perspectives for Bioindication and Phytoremediation. In, Enhancing Cleanup of Environmental Pollutants, 215, Springer, Cham, 2017.

14. ALMÉCIJA C., COBELO-GARCÍA A., SANTOSECHEANDÍA J., CAETANO M. Platinum in salt marsh sediments: Behavior and plant uptake. Mar Chem 185, 91, 2016.

15. FEICHTMEIER N., LEOPOLD K. Bioavailability of Platinum Group Elements to Plants - A Review. In, Platinum Metals in the Environment, 311, Springer, Berlin, Heidelberg, 2015.

16. SCHÄFER J., HANNKER D., ECKHARDT J-D., STÜBEN D. Uptake of traffic-related heavy metals and platinum group elements (PGE) by plants. Sci Total Environ 215, 59, 1998. 
17. EMAMVERDIAN A., DING Y., MOKHBERDORAN F., XIE Y. Heavy Metal Stress and Some Mechanisms of Plant Defense Response. Sci World J 2015, 1, 2015.

18. HASAN M.K., CHENG Y., KANWAR M.K., CHU X-Y., AHAMMED G.J., QI Z-Y. Responses of Plant Proteins to Heavy Metal Stress - A Review. Front Plant Sci 8 (1492), $1,2017$.

19. RAJEWSKA I., TALAREK M., BAJGUZ A. Brassinosteroids and Response of Plants to Heavy Metals Action. Front Plant Sci 7 (629), 1, 2016.

20. RODRIGO M.A.M., ANJUM N.A., HEGER Z., ZITKA O., VOJTECH A., PEREIRA E., KIZEK R. Role of Phytochelatins in Redox Caused Stress in Plants and Animals, Abiotic and Biotic Stress in Plants - Recent Advances and Future Perspectives, InTech, 395, 2016.

21. KOWALSKA J., KIŃSKA K., SADOWSKA M., BIESAGA M., KRASNODĘBSKA-OSTRĘGA B. The role of phytochelatins in Sinapis alba L. response to stress caused by two toxic elements As and Tl. Int J Environ Anal Chem 95, 1148, 2015.

22. NGUYEN X-V., LE-HO K-H., PAPENBROCK J. Phytochelatin 2 accumulates in roots of the seagrass Enhalus acoroides collected from sediment highly contaminated with lead. BioMetals 30, 249, 2017.

23. MIKULASKOVA H., MERLOS M.A.R., ZITKA O., KOMINKOVA M., HYNEK D., ADAM V., BEKLOVA M., KIZEK R. Employment of Electrochemical Methods for Assessment of the Maize (Zea mays L.) and Pea (Pisum sativum L.) Response to Treatment with Platinum(IV). Int J Electrochem Sci 8, 4505, 2013.

24. KOWALSKA J., KIŃSKA K., BIESAGA M., ASZTEMBORSKA M. Application of selective extraction and reverse phase chromatography with three detectors PAD, FLD and ESI MS for characterization of platinum metabolites and identification of phytochelatins in Sinapis alba L. tissues. Microchem J 132, 198, 2017.

25. LEŚNIEWSKA B.A., MESSERSCHMIDT J., JAKUBOWSKI N., HULANICKI A. Bioaccumulation of platinum group elements and characterization of their species in Lolium multiflorum by size-exclusion chromatography coupled with ICP-MS. Sci Total Environ 322, 95, 2004.

26. JEDYNAK L., KOWALSKA J. Stability of arsenic species in hydroponic media and its influence on arsenic uptake and distribution in White mustard (Sinapis alba L.). Microchem J 98, 163, 2011.

27. BLUEMLEIN K., RAAB A., MEHARG A.A., CHARNOCK J.M., FELDMANN J. Can we trust mass spectrometry for determination of arsenic peptides in plants: comparison of LC-ICP-MS and LC-ES-MS/ICPMS with XANES/EXAFS in analysis of Thunbergia alata. Anal Bioanal Chem 390, 1739, 2008.

28. KRASNODĘBSKA-OSTRĘGA B., SADOWSKA M., OSTROWSKA S. Thallium speciation in plant tissues $\mathrm{Tl}(\mathrm{III})$ found in Sinapis alba L. grown in soil polluted with tailing sediment containing thallium minerals. Talanta $\mathbf{9 3}$, 326, 2012.

29. MAZUR R., SADOWSKA M., KOWALEWSKA Ł., ABRATOWSKA A., KALAJI H.M., MOSTOWSKA A., GARSTKA M., KRASNODĘBSKA-OSTRĘGA B. Overlapping toxic effect of long term thallium exposure on white mustard (Sinapis alba L.) photosynthetic activity. BMC Plant Biol 16 (191), 1, 2016.

30. SADOWSKA M., BIADUŃ E., KRASNODĘBSKAOSTREGA B. Stability of Tl(III) in the context of speciation analysis of thallium in plants. Chemosphere 144, 1216, 2016. 